\title{
Upgrading of heavy oil by dispersed biogenic magnetite catalysts
}

DOI:

10.1016/j.fuel.2016.08.015

\section{Document Version}

Accepted author manuscript

Link to publication record in Manchester Research Explorer

\section{Citation for published version (APA):}

Brown, A., Hart, A., Coker, V., Lloyd, J., \& Wood, J. (2016). Upgrading of heavy oil by dispersed biogenic magnetite catalysts. Fuel, 185, 442-448. https://doi.org/10.1016/j.fuel.2016.08.015

\section{Published in:}

Fuel

\section{Citing this paper}

Please note that where the full-text provided on Manchester Research Explorer is the Author Accepted Manuscript or Proof version this may differ from the final Published version. If citing, it is advised that you check and use the publisher's definitive version.

\section{General rights}

Copyright and moral rights for the publications made accessible in the Research Explorer are retained by the authors and/or other copyright owners and it is a condition of accessing publications that users recognise and abide by the legal requirements associated with these rights.

\section{Takedown policy}

If you believe that this document breaches copyright please refer to the University of Manchester's Takedown Procedures [http://man.ac.uk/04Y6Bo] or contact uml.scholarlycommunications@manchester.ac.uk providing relevant details, so we can investigate your claim.

\section{OPEN ACCESS}




\section{Upgrading of heavy oil by dispersed biogenic magnetite catalysts}

2 Ashley R. Brown ${ }^{\mathrm{a} 1}$, Abarasi Hart ${ }^{\mathrm{b}}$, Victoria S. Coker ${ }^{\mathrm{a}}$, Jonathan R. Lloyd $\mathrm{d}^{\mathrm{a} *}$ and Joseph Wood ${ }^{\mathrm{b} *}$

$3 \quad{ }^{a}$ Williamson Research Centre for Molecular Environmental Science, School of Earth,

4 Atmospheric and Environmental Sciences, University of Manchester, Manchester, M13 9PL,

$5 \quad$ United Kingdom.

$6{ }^{b}$ School of Chemical Engineering, University of Birmingham, Edgbaston, Birmingham, B15

$7 \quad 2 T T$, United Kingdom.

$8{ }^{1}$ Present address: Eawag, Swiss Federal Institute of Aquatic Science and Technology, 8600

9 Duebendorf, Switzerland. Email: ashley.brown@eawag.ch

10 *Corresponding authors: ashley.r.brown@manchester.ac.uk; jon.lloyd@manchester.ac.uk;

11 j.wood@bham.ac.uk

\section{Keywords}

THAI, CAPRI, magnetite, palladium, catalyst, heavy oil

\section{Abstract}

In situ catalytic upgrading of heavy oil offers significant cost savings and overcomes logistical challenges associated with the high viscosity, low API gravity and high molecular weight fractions of unconventional hydrocarbon resources. The THAI-CAPRI process (toe-to-heel air injection - catalytic upgrading process in situ) offers one such route to upgrading through the use of high surface area transition metal cracking catalysts surrounding the production well. Here, we describe the catalytic upgrading of heavy oil in a stirred batch reactor by a 
biogenic nanoscale magnetite $\left(\mathrm{BnM} \mathrm{Fe}_{3} \mathrm{O}_{4}\right)$. A $97.8 \%$ decrease in viscosity relative to the feed oil was achieved and coking was lower compared to thermal cracking alone $(6.9$ wt\% versus $10.2 \mathrm{wt} \%)$. The activity of this catalyst was further enhanced by a simple one-step addition of surface associated Pd to achieve loadings of $4.3,7.1$ and $9.5 \mathrm{wt} \% \mathrm{Pd}$. This led to significant decreases in viscosity of up to $99.4 \%$ for BnM loaded with 9.5 wt\% Pd. An increment of $7.8^{\circ}$ in API gravity with respect to the feed oil was achieved for $9.5 \mathrm{wt} \% \mathrm{Pd}$ $\mathrm{BnM}$, compared with thermal cracking alone $\left(5.3^{\circ}\right)$. Whilst this level of upgrading was comparable to commercially available and previously tested catalysts, significant decreases in the coke content ( 3 wt\% for 9.5 wt\% Pd-BnM versus 10 wt\% for thermal cracking) and associated increases in liquid content ( 90 wt\% for 9.5 wt\% Pd-BnM versus $~ 79$ wt\% for thermal cracking) demonstrate the potential for the use of Pd-augmented biogenic magnetite as a catalyst in the THAI CAPRI process.

\section{Introduction}

Continuing depletion of global oil reserves has led to unconventional oil resources, such as oil sands, heavy oil and bitumen becomingly increasingly attractive for exploitation. However, heavy oil and bitumen have the disadvantage of high viscosity, low API (American Petroleum Institute) gravity and high molecular weight fractions. This presents a challenge, as the transportation of these materials is both costly and energetically expensive, with heating of the pipeline or solvent addition often required to improve flow rates [1]. Furthermore, conventional oil refineries require heavy oil and bitumen to be first upgraded to a light crude oil before being distilled [2]. Again, this carries associated costs and hence previous exploitation of these resources has been limited. 
This demand for enhanced oil recovery (EOR) has led to the development of in situ upgrading technologies [3]. These present the key advantage that upgrading occurs downhole, thus, enhancing both production and oil quality whilst precluding the need for a secondary surface upgrading facility. In addition, several environmental benefits are offered as unwanted contaminants or by-products are retained in the reservoir, including heavy metals, sulphur and carbon dioxide [4].

The THAI-CAPRI process (toe-to-heel air injection; catalytic upgrading process in situ) is one such technique that combines thermally enhanced oil recovery with in situ catalysis of the heavy oil being mobilised [5-7]. First, in situ combustion is advanced by the continuous injection of air through a vertical well (THAI), which allows the combustion front to be sustained. Second, the CAPRI add-on involves the addition of a catalyst to the horizontal production well, which promotes upgrading of the mobilised oil, e.g. via hydrocracking and hydrodesulfurization. However, challenges arise from the use of fixed bed catalysts due to severe deposition of coke, asphaltenes and metals leading to catalyst deactivation $[8,9]$.

Alternatively, dispersed submicron and nano-particulate catalysts may circumvent this by presenting a larger surface area distributed throughout the site of combustion, and hence, overcoming diffusion limitations and pore plugging associated with fixed bed catalysts, which may obstruct production lines [10-12]. Previous work has shown that dispersed micrometer sized $\mathrm{Co}-\mathrm{Mo} / \mathrm{Al}_{2} \mathrm{O}_{3}$ showed superior upgrading compared to its millimetre sized pelleted counterpart [10]. Significant upgrading has also been described for dispersed nanoparticulate hematite and several un-supported transition metal nanoparticles, namely $\mathrm{MoS}_{2}, \mathrm{NiO}$ and $\mathrm{Fe}_{2} \mathrm{O}_{3}[11,13]$. Although the extent of upgrading was modest compared to 
the remaining coke having a sponge-type character which may find use as an industrial fuel compared with typical coke materials generated from thermal cracking. These studies highlight the potential for the combination of dispersed nano-sized catalysts with the in situ upgrading offered by the CAPRI process, as an alternative to previously used pelleted hydroprocessing catalysts.

Noble metals, such as palladium and platinum also exhibit catalytic upgrading of oil through the promotion of hydrogenation and hydrogenolysis reactions which add hydrogen to the oil molecule (hydrocracking) [14-16]. Supported-Pd catalysts are particularly effective, as the surface area of the palladium is maximised by a nanoparticulate support structure. Typically, this has been done with carbon, silica, alumina and recently bacterial biomass $[14,16,17]$. Indeed, the use of bacteria in nanocatalyst production represents a more environmentally benign synthesis route.

Further work using bacteria has demonstrated the synthesis of magnetic iron oxide nanoparticles using Fe(III)-reducing bacteria such as Geobacter sulfurreducens [18,19]. Biogenic nanoscale magnetite (bionanomagnetite; $\mathrm{BnM}$ ) has a large surface area, high chemical reactivity and exhibits effective reduction of a range of organics and metals, being notably more efficient at reducing $\mathrm{Cr}(\mathrm{VI})$ than a commercially available synthetic $\mathrm{Fe}_{3} \mathrm{O}_{4}$ $[20,21]$. Importantly, the particle size of this potential catalyst support can be manipulated during its microbial synthesis, permitting its optimization for novel uses during scalable production [22].

Furthermore, biogenic magnetite is very amenable to surface functionalization with other transition metals such as palladium, mediated by reactive surface $\mathrm{Fe}(\mathrm{II})$ and an organic layer facilitating reductive precipitation and attachment of $\mathrm{Pd}(0)$ [19]. Pd-biomagnetite is highly 
reactive toward $\mathrm{Cr}(\mathrm{VI})$ and is efficient in hydrogenation of nitroaromatic hydrocarbons and halogenated solvents $[21,23,24]$. Additionally, when tested in a Heck reaction, coupling iodobenzene to ethyl acrylate or styrene, reaction rates using $\mathrm{Pd}$-biomagnetite were superior or equal to an equimolar amount of commercially available colloidal Pd catalyst [19]. Although Pd is expensive to apply in an oil upgrading process, the cost could potentially be reduced by utilising metal recovered from secondary sources such as electronic waste, scrap catalytic converters or even low grade road dust, which contains traces of platinum group metals exhausted from automotive catalysts $[25,26]$. In addition, the use of magnetite drawback for other precious metal catalyst supports [27].

\section{Material and Methods}

\subsection{Bionanomagnetite ( $\mathrm{BnM})$ catalyst preparations.}

Biogenic magnetite was synthesised by the dissimilatory reduction of $\mathrm{Fe}(\mathrm{III})$ in a ferrihydrite suspension, by late-log phase cultures of Geobacter sulfurreducens as described previously $[19,23,24,28,29]$. 
First, ferrihydrite was synthesised by the rapid hydrolysis of a $0.6 \mathrm{M} \mathrm{Fe}(\mathrm{III})$ chloride solution via the dropwise addition of $1 \mathrm{M} \mathrm{NaOH}$ to $\mathrm{pH} 7$, whilst stirring vigorously [30]. The resultant precipitate was washed six times by centrifugation at $5000 \mathrm{~g}$ for $20 \mathrm{~min}$, followed by removal of the supernatant and resuspension in $18 \mathrm{M} \Omega$ de-ionised water.

A culture of $G$. sulfurreducens was grown in a modified freshwater basal medium containing $20 \mathrm{mM}$ acetate and $40 \mathrm{mM}$ fumarate as electron donor and acceptor respectively [31]. Cultures were grown to late log-early stationary phase at $30^{\circ} \mathrm{C}$ under an $80: 20 \mathrm{~N}_{2}-\mathrm{CO}_{2}$ atmosphere [31]. Cells were then harvested by centrifugation at $5000 \mathrm{~g}$ for $20 \mathrm{~min}$ and washed three times in sterile $30 \mathrm{mM} \mathrm{NaHCO}_{3}$ at $\mathrm{pH} 7$.

For magnetite production, $1 \mathrm{~L}$ of autoclaved medium was prepared containing $20 \mathrm{mM}$ acetate, $100 \mathrm{mM} \mathrm{Fe}$ (as ferrihydrite), $30 \mathrm{mM} \mathrm{NaHCO}$ and $10 \mu \mathrm{M}$ anthraquinone-2,6carbon support films (Agar Scientific). 
The surface of biogenic magnetite crystallites was functionalized with various wt\% Pd loadings (\% Pd by mass of BnM) according to methods described previously [19,23].

Precipitation of Pd onto magnetite was achieved via surface Fe(II)-mediated reductive precipitation from a $\mathrm{N}_{2}$ sparged solution of $\mathrm{Na}_{2} \mathrm{Pd}(\mathrm{II}) \mathrm{Cl}_{4}$. Bottles containing the magnetite suspended in $\mathrm{Pd}(\mathrm{II})$-containing solutions were agitated on rollers for $12 \mathrm{~h}$ in the dark. Excess ions were then removed by washing three times in $18 \mathrm{M} \Omega$ de-ionised water under an $\mathrm{N}_{2}$ atmosphere. Suspensions were then re-suspended in acetone so that the suspensions would be miscible with the oil for reactor tests. Prior to testing, $1 \mathrm{~mL}$ aliquots were removed, centrifuged at $5000 \mathrm{~g}$ for $5 \mathrm{~min}$ and the supernatant aliquots were analysed by ICP-AES to confirm the removal of Pd from solution. The remaining solid material was digested in $3 \mathrm{M}$ $\mathrm{HCl}$ and again analysed by ICP-AES to determine the final Fe concentrations and Pd wt\% loadings achieved.

\subsection{Optimization of Pd loading and reactivity on BnM.}

To optimize the wt\% Pd loading and reactivity on magnetite surfaces, materials were produced as before but with the inclusion of $\mathrm{H}_{2}$ sparging steps, followed by the addition of $\mathrm{Fe}(\mathrm{II})$ aqueous solutions in order to increase surface-sorbed Fe(II). These two steps aimed to provide excess electron donors for the enhanced reductive precipitation of $\mathrm{Pd}$ on to the magnetite surfaces. First, magnetite suspensions were dispersed by sonication in a water bath for $5 \mathrm{~min}$ and then sparged with $\mathrm{H}_{2}$ for $1 \mathrm{~min}$. A $1 \mathrm{~mL}$ solution of $\mathrm{N}_{2}$ sparged $100 \mathrm{mM}$ $\mathrm{Fe}(\mathrm{II}) \mathrm{SO}_{4} \cdot 7 \mathrm{H}_{2} \mathrm{O}$ was then added to the suspensions, followed by sonication for 5 mins and sparging with $\mathrm{H}_{2}$ for 1 min. An $\mathrm{N}_{2}$ sparged solution of $\mathrm{Na}_{2} \mathrm{Pd}(\mathrm{II}) \mathrm{Cl}_{4}$ was added, providing sufficient Pd to achieve a loading of $20 \mathrm{wt} \% \mathrm{Pd}$. As before, bottles were agitated on rollers for 12 hours in the dark. Finally, the suspensions were washed three times in $18 \mathrm{M} \Omega$ de- 
ionised water, and three times in acetone to suspend the Pd-BnM in an oil miscible solvent and to remove excess ions. Pd loadings were confirmed as described above.

\subsection{Reactor tests.}

The heavy oil used in this study was supplied by Petrobank Energy and Resources Ltd (now Touchstone Exploration Inc.), Canada. The initial API gravity and viscosity were $13.9^{\circ}$ and $952 \mathrm{mPa}$.s. Prior to addition of the Pd-BnM preparations to the batch catalytic reactor, the with the ASTM D2887 standard test method. Macromolecules, such as resins and asphaltenes, cannot be accounted for in this method, since the calibration mix contained 
only hydrocarbons from $C_{5}$ to $C_{40}$ ). A detailed description of these instruments and techniques can be found in $[9,32,33]$.

The portion of the carbonaceous deposit after reaction that represented coke was determined using thermogravimetric analysis (TGA). The carbonaceous deposits left in the reactor, which are a composite of coke, residual oil, asphaltenes and catalyst nanoparticles, were collected and burnt off in a Thermogravimetric Analyser (NETZSCH-Geratebau GmbH, TG 209 F1 Iris ${ }^{\circledR}$ ). The analysis was performed using a ramp temperature increase from 25 to $900{ }^{\circ} \mathrm{C}$ with an air flow rate of $50 \mathrm{~mL} \mathrm{~min}{ }^{-1}$. The amount of coke in the deposit was determined from the temperature-weight loss curve. Previous analyses under the same experimental conditions have established the temperatures at which residual oil ( 25 to 410 result in only negligible effects on the recorded mass distributions of reaction products.

The non-condensable gas yields after the upgrading reaction was determined by subtracting the mass of the autoclave contents after reaction from the mass of heavy oil prior to reaction.

\section{Results and Discussion}

\subsection{Characterisation of bionanomagnetite.}

The microbial production of nano-scale magnetite was achieved via the respiratory reduction of Fe(III), present as a ferrihydrite "gel", by anoxic washed cell suspensions of the 
subsurface Fe(III)-reducing bacterium G. sulfurreducens. Complete conversion to magnetite occurred in less than $24 \mathrm{~h}$. The biosynthesis of a pure magnetite product was confirmed by both TEM and powder XRD (Figure 1). TEM further confirmed that the morphology and particle size (15 to $30 \mathrm{~nm}$ ) was very similar to that reported previously $[19,20,23,29]$. The surface area of biomagnetite, generated using the same production methods, has been reported previously by our laboratory as $17.1 \mathrm{~m}^{2} \mathrm{~g}^{-1}$ [29]. However, this figure should be regarded as an estimate due to particle aggregation that routinely arises during preparation and measurement using the BET $\mathrm{N}_{2}$ adsorption method.

Previous studies have demonstrated that the surface of biogenic magnetite can be functionalised with $\mathrm{Pd}(0)$ via surface $\mathrm{Fe}(\mathrm{II})$-mediated reductive precipitation from a $\mathrm{N}_{2}$ sparged solution of $\mathrm{Na}_{2} \mathrm{Pd}(\mathrm{II}) \mathrm{Cl}_{4}[19,23]$. Initially, two loadings of 4.3 and $7.1 \mathrm{wt} \% \mathrm{Pd}$ were achieved by supplying magnetite with $\mathrm{Pd}(\mathrm{II})$ concentrations that should have been sufficient for 5 and 20 wt\% Pd, respectively, if all the supplied Pd(II) was reduced. This suggests that 7.1 wt\% Pd was the maximum Pd loading achievable via this first method. XRD confirmed that solid phase Pd was associated with the magnetite (Figure 2). Using the same synthesis methods as used here, Coker et al. (2010) report that for bionanomagnetite augmented with 5 mol.\% Pd, particles of palladium (approx. $5 \mathrm{~nm}$ ) were precipitated onto the larger magnetite structures (approx. $20 \mathrm{~nm}$ ), as observed via TEM.

After further optimization, involving $\mathrm{H}_{2}$ sparging steps followed by addition of aqueous $\mathrm{Fe}(\mathrm{II})$ to magnetite suspensions (described in detail above), a Pd loading of $9.5 \mathrm{wt} \% \mathrm{Pd}$ was achieved. This increased loading is likely a result of the addition of these reductants, with both $\mathrm{H}_{2}$ and $\mathrm{Fe}(\mathrm{II})$ enhancing the reductive precipitation of $\mathrm{Pd}$ onto magnetite surfaces. 
Despite an excess of $\mathrm{Pd}(\mathrm{II})$ supplied, the final loading of $9.5 \mathrm{wt} \% \mathrm{Pd}$ likely represents the upper limit of Pd-loading achievable using the protocols described here.

\subsection{Catalytic upgrading of oil by palladised biogenic magnetite.}

232

The yield balance between liquid (upgraded oil), gas and coke as well as the upgraded oil API gravity and viscosity relative to the feed oil after upgrading experiments are displayed in Table 1. It can be seen that the liquid and coke yields after upgrading are inversely correlated, as an increase in liquid yield correspond to a decrease in coke yield. Whilst thermal cracking produced the lowest yield of upgraded oil (78.8wt\%) and the highest coke yield (10.2 wt\%), catalytic upgrading with bionanomagnetite (BnM) yielded 82.3 wt\% upgraded oil and $6.9 \mathrm{wt} \%$ coke. Increasing the loadings of palladium (Pd) onto the $\mathrm{BnM}$ from 4.3 to $9.5 \mathrm{wt} \%$, led to a corresponding increase in the upgraded oil yield from 82.3 to $89.6 \mathrm{wt} \%$, and a decrease in coke from 6.9 to $3.0 \mathrm{wt} \%$. A similar observation has been reported for thermal cracking relative to catalytic upgrading by Hart et al. [9] and AlMarshed et al. [13]. It has been reported that thermal cracking proceeds by a free radical mechanism that promotes the precipitation of coke precursors, such as resins and asphaltenes. Consequently, polymerisation and condensation occurs, as the abstraction of hydrogen, methyl, ethyl and other material from deposited polyaromatic species to the gas phase occurs, resulting in significant coke formation. However, previous work has demonstrated that catalysts bearing various transition metals display reduced coke yields and corresponding increases in upgraded oil yields. As such, the addition of BnM augmented with Pd may also exhibit the ability to transfer hydrogen, methyl and other material from the gas into the oil phase [13]. This is consistent with the observation that thermal cracking 
alone produced more gas (11 wt\%) relative to upgrading by $\mathrm{BnM}(10.8 \mathrm{wt} \%)$ and $\mathrm{BnM}+9.5$

$252 \quad w t \% \operatorname{Pd}(7.4 w t \%)$.

Table 1. Mass distributions of liquid, gas and coke, and API gravity and viscosity of oil before and after thermal cracking or reaction with $\mathrm{BnM}$, with and without added Pd. Results for $\mathrm{CoMo} / \mathrm{Al}_{2} \mathrm{O}_{3}[34]$ and $\mathrm{NiMo} / \mathrm{Al}_{2} \mathrm{O}_{3}[36]$, as typical refinery catalysts are shown for comparison.

\begin{tabular}{|c|c|c|c|c|c|}
\hline & Liquid & Gas & Coke & API gravity & Viscosity \\
\hline Sample & (wt\%) & (wt\%) & (wt\%) & $\left({ }^{\circ}\right)$ & (mPa.s) \\
\hline Feed oil & & & & 13.2 & 1031 \\
\hline Thermal cracking & $78.8 \pm 0.2$ & $11.0 \pm 0.3$ & $10.2 \pm 0.6$ & $18.5 \pm 0.5$ & $28.3 \pm 2.1$ \\
\hline $\mathrm{Co}-\mathrm{Mo} / \mathrm{Al}_{2} \mathrm{O}_{3}$ & $80.8 \pm 0.1$ & $7.1 \pm 0.5$ & $12.2 \pm 0.1$ & $23.6 \pm 0.2$ & $4.4 \pm 1.3$ \\
\hline $\mathrm{Ni}-\mathrm{Mo} / \mathrm{Al}_{2} \mathrm{O}_{3}$ & $87.3 \pm 0.5$ & $7.7 \pm 0.7$ & $5.0 \pm 0.8$ & $24.9 \pm 0.3$ & $3.7 \pm 0.6$ \\
\hline $\mathrm{BnM}$ & $82.3 \pm 0.3$ & $10.8 \pm 0.2$ & $6.9 \pm 0.4$ & $18.7 \pm 0.3$ & $22.6 \pm 1.7$ \\
\hline $\mathrm{BnM}+4.3 w \mathrm{t} \% \mathrm{Pd}$ & $85.2 \pm 0.2$ & $8.9 \pm 0.1$ & $5.9 \pm 0.3$ & $20.6 \pm 0.3$ & $17.8 \pm 1.1$ \\
\hline$B n M+7.1 w t \% P d$ & $83.7 \pm 0.4$ & $10.9 \pm 0.6$ & $5.4 \pm 0.2$ & $19.9 \pm 0.4$ & $15.6 \pm 2.3$ \\
\hline $\mathrm{BnM}+9.5$ wt\% Pd & $89.6 \pm 0.7$ & $7.4 \pm 0.3$ & $3.0 \pm 0.4$ & $21.0 \pm 0.2$ & $5.9 \pm 0.8$ \\
\hline
\end{tabular}

259 The viscosity and API gravity of crude oil are properties that determine its value, refineability and ease of pipeline transportation. The API gravity of the upgraded oil improved 261 from $13.2^{\circ}$ (feedstock) to $18.5^{\circ}$ (thermal cracking), $18.7^{\circ}$ (BnM only) and $21.0^{\circ}$ (BnM +9.5 
$w t \%$ Pd), a $159 \%$ increase in the case of the latter. Conversely, the viscosity of upgraded oil decreased significantly from $1031 \mathrm{mPa} \cdot \mathrm{s}$ (feedstock) to $28.3 \mathrm{mPa} \cdot \mathrm{s}$ (thermal cracking), 22.6 $\mathrm{mPa} \cdot \mathrm{s}$ (BnM only) and $5.9 \mathrm{mPa} \cdot \mathrm{s}(\mathrm{BnM}+9.5 \mathrm{wt} \% \mathrm{Pd})$, a 99.4\% decrease. This magnitude of viscosity reduction is capable of improving production and pipeline transportation owing to the level of fluidity experienced at lower viscosity [37]. Similar improvements in catalytically upgraded oil versus thermally cracked heavy oil using conventional, chemically synthesised catalysts has been reported by Hart et al. $[9,32,33]$. In the absence of a transition metal oxide catalyst, free radicals lead to adduct formation as a result of the addition reaction between two or more active hydrocarbon chains. This, in turn, leads to the formation of larger molecular weight hydrocarbons, which limits any increase in the API gravity or decreases in viscosity of the produced oil $[37,38]$. However, the presence of a transition metal oxide catalyst, such as $\mathrm{BnM}$, likely promotes hydrogen-transfer reactions between hydrocarbons in the gas and liquid phases, which helps to cap free radicals once they are Pd on BnM increases from 4.3 to 9.5 wt\%.

The extent of the improvement in API gravity and viscosity with increasing Pd loading may be limited due to the sulfur content of the heavy oil (3.52 wt\%). It has been reported that surfaces [39], which may have impeded the activity and performance of the particles. Indeed a similar effect was observed in the testing of palladized iron for the dechlorination of groundwater [40]. The experiments demonstrated that the dechlorination reaction occurred efficiently until the surface of the $\mathrm{Pd} / \mathrm{Fe}$ became fouled. It was found that reduced 
sulfur species could eventually lead to permanent poisoning of the palladium. Contrary to this, other studies have shown that sulfur may prolong the life of platinum group metal catalysts and even promote activity and enhance selectivity $[39,41,42]$. However this phenomenon is typically noted for sulfur concentrations on catalyst surfaces that are significantly lower than that reported for the bulk sulfur content of the heavy oil used in this study (e.g. $<0.5$ wt.\%). Despite this, the authors of a previous study utilising the same native oil and reactor conditions as used here, assumed that although sulfur is present in potentially inhibitory concentrations, it may be present in non-available forms due to its association with other metals present in the native feed oil [34]. Although the extent of sulphur deactivation was not evaluated in this study, the data suggest that the Pd-BnM catalyst performed comparably with typically refinery catalysts (table 1).

The true boiling point (TBP) distribution curves obtained from simulated distillation (SIMDIS) of the feed oil and oils upgraded by thermal cracking and $\mathrm{BnM}$ are presented in Figure 3. The TBP curves show the cumulative volume distilled as a function of temperature. The shift of the TBP curves from reactor tests containing added catalyst to the left of the TBP curve of compared to the feed oil.

A noticeable improvement in the amount of distillate obtainable can be observed between the temperature ranges of 230 to $430{ }^{\circ} \mathrm{C}$, for all reactor tests relative to the feed oil. The TBP curves of the upgraded oils by thermal cracking and BnM only are approximately identical, which is in line with their similar API gravities and viscosities reported in Table 1. However, the addition of Pd to BnM produced a further increase in the amount of distillate fractions distilled between the boiling temperature range of 200 to $450{ }^{\circ} \mathrm{C}$, with significant 
increases recorded when the Pd loading of the BnM was increased to $9.5 \mathrm{wt} \% \mathrm{Pd}$. This observed increase in naphtha and middle distillate fractions upon the increasing addition of $\mathrm{Pd}$ to $\mathrm{BnM}$ can be attributed to the enhanced ability of $\mathrm{Pd}$ to facilitate hydrogenation reactions, compared with Fe. Hence, the synergistic effect of Fe plus Pd enhanced the conversion of high boiling hydrocarbon components into lighter hydrocarbon fractions, relative to that observed for $\mathrm{BnM}$ alone. These trends in TBP curves are in line with the API gravities and viscosities of the upgraded oils, relative to the feed oil, shown in Table 1.

\subsection{Outlook and comparison with commercially available catalysts.}

In summary, the experiments reported here have demonstrated that both biogenic magnetite augmented with $\mathrm{Pd}$ and biogenic magnetite alone are capable of significant catalytic upgrading of oil, as measured by increases in liquid yield, API gravity and corresponding decreases in viscosity. A reduction in coke content and an increase in lighter hydrocarbon fractions further demonstrate the potential for its use as a catalyst in the THAI CAPRI process.

Dispersed nanoparticulate magnetite offers increased oil contact through a large surfacearea-to-volume ratio and decreased diffusion path lengths compared with using fixed-bed reactors $[10,43]$. Indeed, the use of biomagnetite as the catalyst support not only offers catalytic properties itself but also provides a large surface area over which the $\mathrm{Pd}$ is precipitated, facilitated by the large pool of surface associated $\mathrm{Fe}(\mathrm{II})$ that serves as the reductant. As Pd also promotes hydrogenation and hydrogenolysis reactions [14-16], Pdaugmented bionanomagnetite represents a bi-functional catalyst with increased activity and performance. 
Indeed, previous studies have shown that commercially available $\mathrm{Ni}-\mathrm{Mo} / \mathrm{Al}_{2} \mathrm{O}_{3}$ and dispersed ultrafine Co-Mo/ $\mathrm{Al}_{2} \mathrm{O}_{3}$ achieved a higher API gravity increase than the tested catalysts in this study under the same conditions as used here ( 23.6 and $22.5^{\circ}$ respectively) $[34,36]$. However, lower coke contents and a higher liquid yield of 89.6 wt\% using $9.5 w t \%$ Pd-BnM were achieved in this study, compared with 87.3 and 80.8 wt $\%$ for $\mathrm{Ni}-\mathrm{Mo} / \mathrm{Al}_{2} \mathrm{O}_{3}$ and dispersed ultrafine Co- $\mathrm{Mo} / \mathrm{Al}_{2} \mathrm{O}_{3}$, respectively. The coke content of $12.15 \mathrm{wt} \%$ for Co$\mathrm{Mo} / \mathrm{Al}_{2} \mathrm{O}_{3}$ was higher than achieved for all the tested materials reported here, and lower coking was achieved using 9.5 wt\% $\mathrm{Pd}-\mathrm{BnM}(3.0 \mathrm{wt} \%)$ than was reported for $\mathrm{Ni}-\mathrm{Mo} / \mathrm{Al}_{2} \mathrm{O}_{3}$ (5.0 wt \%). As coke production reduces both the liquid yield and the lifetime of the catalyst gravity and viscosity achieved.

Similar comparisons can be made with dispersed transition metal catalysts. $\mathrm{Fe}_{2} \mathrm{O}_{3}, \mathrm{MoS}_{2}$, $\mathrm{MoO}_{3}, \mathrm{FeS}$ and $\mathrm{NiO}$ have all shown slightly higher levels of upgrading in terms of API gravity (typically $\sim 21^{\circ}$ ) $[11,13]$. However, viscosities were all significantly higher for these materials (typically 70 to $140 \mathrm{mPa} \cdot \mathrm{s}$; though this may be due to the slightly different reactor conditions used) and coke levels ( $>4.3 w t \%$ coke) were again, not as low as for 9.5 wt\% PdBnM (3.0wt\% coke).

Recent work has investigated upgrading using nanoparticulate $\mathrm{Pd}$ and $\mathrm{Pt}$ supported on bacterial cell scaffolds, under the same reactor conditions used here $[34,36]$. Using similar Pd loadings, the authors achieved very similar improvements in yields, coking and viscosity, supporting our finding that biotechnological approaches to catalyst synthesis can generate commercially competitive catalysts using "green" biosynthesis routes. 
Whilst such improvements in oil upgrading by $\mathrm{Pd}-\mathrm{BnM}$, compared to those of commercial and other tested materials, may appear modest at the laboratory scale tested here, such incremental changes may lead to significant benefits in process economics at full scale. Recent work has demonstrated that biogenic magnetite production can be successfully scaled up from laboratory to pilot plant-scale whilst controlling its reactivity, magnetic properties and particle size, suggesting that its exploitation in commercial settings are achievable [45]. In addition, the production process may offer a more environmentally benign route to catalyst production than established chemical methods and thus, such environmental benefits may offset the cost of using expensive precious metals, such as palladium [27]. Indeed, recent work suggests that this cost may be further reduced by sourcing metals from electronic waste, scrap catalytic converters or road dust, which contains platinum group metals exhausted from automotive catalysts $[25,26]$. In this context, the competitive results reported here suggest that an economic cost analysis may be warranted.

Finally, our experiments have relied on the laboratory production of magnetite using a pure culture of a model Fe(III)-reducing bacterium. However, the natural occurrence of such species in sub-surface sediments, alongside native Fe(III)-bearing oxides, may represent the potential for the in situ generation of a catalyst. Future experiments will, therefore, focus on achieving the stimulation of such organisms in relevant geological formations and, thus, eliminating the need for delivery of a catalyst to the reaction front of the THAI process. Enhanced oil recovery by such means may further reduce financial overheads associated with the THAI-CAPRI process. 


\section{Acknowledgements.}

378

379

380

381

382

Funding: This work was supported by the UK Engineering and Physical Sciences Research Council (EPSRC; grant number EP/J008303/1). The data from this study are available online via epapers.bham.ac.uk. The authors would like to thank Petrobank Energy and Resources Ltd. and Touchstone Exploration Inc., Canada for supplying the heavy oil used in these experiments. We also thank Prof. Lynne Macaskie, University of Birmingham, for advice and helpful discussions; Paul Lythgoe, Manchester Analytical Geochemistry Unit, for ICP-AES analyses; Dr. John Waters for XRD and Dr. Mike Ward, University of Leeds EPSRC Nanoscience and Nanotechnology Facility, for TEM.

\section{References}

[1] Martinez-Palou R, Mosqueira M de L, Zapata-Rendon B, Mar-Juarez E, BernalHuicochea C, de la Cruz Clavel-Lopez J, et al. Transportation of heavy and extra-heavy crude oil by pipeline: A review. J Pet Sci Eng 2011;75:274-82. doi:10.1016/j.petrol.2010.11.020.

[2] Carrillo JA, Corredor LM. Upgrading of heavy crude oils: Castilla. Fuel Process Technol 2013;109:156-62. doi:10.1016/j.fuproc.2012.09.059.

[3] Weissman JG, Kessler R V, Sawicki RA, Belgrave JDM, Laureshen CJ, Mehta SA, et al. Down-Hole Catalytic Upgrading of Heavy Crude Oil. Energy \& Fuels 1996;10:883-9. doi:10.1021/ef9501814.

[4] Shah A, Fishwick R, Wood J, Leeke G, Rigby S, Greaves M. A review of novel techniques for heavy oil and bitumen extraction and upgrading. Energy Environ Sci 
400

401

402

403

404

405

406

407

408

409

410

411

412

413

414

415

416

417

418

419

420

[5] Xia TX, Greaves M. Upgrading Athabasca tar sand using toe-to-heel air injection. J Can Pet Technol 2002;41.

[6] Xia TX, Greaves M, Turta AT, Ayasse C. THAI - A "short-distance Displacement" in situ combustion process for the recovery and upgrading of heavy oil. Chem Eng Res Des 2003;81:295-304. doi:10.1205/02638760360596847.

[7] Greaves M, El-Saghr A, Xia TX. CAPRI horizontal well reactor for catalytic upgrading of heavy oil: Advances in oil field chemistry: Downhole upgrading. Prepr Chem Soc Div Pet Chem 2000;45:595-8.

[8] Shah A, Fishwick RP, Leeke GA, Wood J, Rigby SP, Greaves M. Experimental optimization of catalytic process in situ for heavy-oil and bitumen upgrading. J Can Pet Technol 2011;50:33-47. doi:10.2118/136870-PA.

[9] Hart A, Shah A, Leeke G, Greaves M, Wood J. Optimization of the CAPRI process for heavy oil upgrading: Effect of hydrogen and guard bed. Ind Eng Chem Res 2013;52:15394-406. doi:10.1021/ie400661x.

[10] Hart A, Greaves M, Wood J. A comparative study of fixed-bed and dispersed catalytic upgrading of heavy crude oil using-CAPRI. Chem Eng J 2015;44:1-11. doi:10.1016/j.cej.2015.01.101.

[11] Al-Marshed A, Hart A, Leeke G, Greaves M, Wood J. Optimization of heavy oil upgrading using dispersed nanoparticulate iron oxide as a catalyst. Energy \& Fuels 2015;29:6306-16.

[12] Hashemi R, Nassar NN, Pereira Almao P. Nanoparticle technology for heavy oil in-situ 
upgrading and recovery enhancement: Opportunities and challenges. Appl Energy 2014;133:374-87. doi:10.1016/j.apenergy.2014.07.069.

[13] Al-Marshed A, Hart A, Leeke G, Greaves M, Wood J. Effectiveness of different transition metal dispersed catalysts for in situ heavy oil upgrading. Ind Eng Chem Res 2015;54:10645-55.

[14] Wood J, Bodenes L, Bennett J a, Deplanche K, Macaskie LE. Hydrogenation of 2Butyne-1,4-diol Using Novel Bio-Palladium Catalysts. Ind Eng Chem Res 2010;49:9808. doi:10.1021/ie900663k.

[15] Del Bianco A, Panariti N, Di Carlo S, Elmouchnino J, Fixari B, Le Perchec P. Thermocatalytic hydroconversion of heavy petroleum cuts with dispersed catalyst. Appl Catal A Gen 1993;94:1-16. doi:http://dx.doi.org/10.1016/0926-860X(93)80041N.

[16] Schüth C, Reinhard M. Hydrodechlorination and hydrogenation of aromatic compounds over palladium on alumina in hydrogen-saturated water. Appl Catal B Environ 1998;18:215-21. doi:10.1016/S0926-3373(98)00037-X.

[17] Chaplin BP, Reinhard M, Schneider WF, Schüth C, Shapley JR, Strathmann TJ, et al. Critical Review of Pd-Based Catalytic Treatment of Priority Contaminants in Water. Environ Sci Technol 2012;46:3655-70. doi:10.1021/es204087q.

[18] Coker VS, Telling ND, van der Laan G, Pattrick RAD, Pearce Cl, Arenholz E, et al. Harnessing the Extracellular Bacterial Production of Nanoscale Cobalt Ferrite with Exploitable Magnetic Properties. ACS Nano 2009;3:1922-8. doi:10.1021/nn900293d.

[19] Coker VS, Bennett JA, Telling ND, Henkel T, Charnock JM, van der Laan G, et al. Microbial engineering of nanoheterostructures: biological synthesis of a magnetically 
recoverable palladium nanocatalyst. ACS Nano 2010;4:2577-84. doi:10.1021/nn9017944.

[20] Cutting RS, Coker VS, Telling ND, Kimber RL, Pearce Cl, Ellis BL, et al. Optimizing Cr(VI) and Tc (VII) remediation through nanoscale biomineral engineering. Environ Sci Technol 2010;44:2577-84.

[21] Watts MP. Novel bionanotechnological approaches for the remediation of contaminated land. University of Manchester, 2014.

[22] Byrne JM, Telling ND, Coker VS, Pattrick RAD, Van Der Laan G, Arenholz E, et al. Control of nanoparticle size, reactivity and magnetic properties during the bioproduction of magnetite by Geobacter sulfurreducens. Nanotechnology 2011;22:455709.

[23] Watts MP, Coker VS, Parry SA, Thomas RAP, Kalin R, Lloyd JR. Effective treatment of alkaline $\mathrm{Cr}(\mathrm{VI})$ contaminated leachate using a novel Pd-bionanocatalyst: Impact of electron donor and aqueous geochemistry. Appl Catal B Environ 2015;170-171:16272. doi:10.1016/j.apcatb.2015.01.017.

[24] Crean DE, Coker VS, van der Laan G, Lloyd JR. Engineering biogenic magnetite for sustained $\mathrm{Cr}(\mathrm{VI})$ remediation in flow-through systems. Environ Sci Technol 2012;46:3352-9. doi:10.1021/es2037146.

[25] Murray AJ. Recovery of Platinum Group Metals from Spent Furnace Linings and Used Automotive Catalysts. University of Birmingham, 2012.

[26] Macaskie LE, Mikheenko IP, Yong P, Deplanche K, Murray AJ, Paterson-Beedle M, et al. Today's wastes, tomorrow's materials for environmental protection. Hydrometallurgy 2010;104:483-7. doi:10.1016/j.hydromet.2010.01.018. 
467

[27] Lloyd JR, Byrne JM, Coker VS. Biotechnological synthesis of functional nanomaterials. Curr Opin Biotechnol 2011;22:509-15. doi:10.1016/j.copbio.2011.06.008.

[28] Cutting RS, Coker VS, Fellowes JW, Lloyd JR, Vaughan DJ. Mineralogical and morphological constraints on the reduction of Fe(III) minerals by Geobacter sulfurreducens. Geochim Cosmochim Acta 2009;73:4004-22. doi:DOI 10.1016/j.gca.2009.04.009.

[29] Watts MP, Coker VS, Parry SA, Pattrick RAD, Thomas RAP, Kalin R, et al. Biogenic nano-magnetite and nano-zero valent iron treatment of alkaline $\mathrm{Cr}(\mathrm{VI})$ leachate and chromite ore processing residue. Appl Geochemistry 2015;54:27-42. doi:10.1016/j.apgeochem.2014.12.001.

[30] Lovley DR, Phillips EJP. Organic matter mineralization with reduction of ferric iron in anaerobic sediments. Appl Environ Microbiol 1986;51:683-9.

[31] Lloyd JR, Leang C, Hodges Myerson AL, Coppi M V, Cuifo S, Methe B, et al. Biochemical and genetic characterization of PpcA, a periplasmic c-type cytochrome in Geobacter sulfurreducens. Biochem J 2003;369:153-61. doi:10.1042/BJ20020597 BJ20020597 [pii].

[32] Hart A, Leeke G, Greaves M, Wood J. Down-hole heavy crude oil upgrading by CAPRI: Effect of hydrogen and methane gases upon upgrading and coke formation. Fuel 2014;119:226-35. doi:10.1016/j.fuel.2013.11.048.

[33] Hart A, Lewis C, White T, Greaves M, Wood J. Effect of cyclohexane as hydrogendonor in ultradispersed catalytic upgrading of heavy oil. Fuel Process Technol 2015;138:724-33.

[34] Hart A, Omajali JB, Murray AJ, Macaskie LE, Greaves M, Wood J. Comparison of the 
effects of dispersed noble metal (Pd) biomass supported catalysts with typical hydrogenation (Pd/C, Pd/Al2O3) and hydrotreatment catalysts (CoMo/Al2O3) for insitu heavy oil upgrading with Toe-to-Heel Air Injection (THAI). Fuel 2016;180:367-76.

[35] Cornell RM, Schwertmann U. The iron oxides. Second. Weinheim: WILEY-VCH Verlag; 2003.

[36] Omajali J. Novel bionanocatalysts for green chemistry applications. University of Birmingham, 2015.

[37] Hart A. Advanced studies of catalytic upgrading of heavy oils. University of Birmingham, UK, 2014.

[38] Habib FK, Diner C, Stryker JM, Semagina N, Gray MR. Suppression of addition reactions during thermal cracking using hydrogen and sulfided iron catalyst. Energy \& Fuels 2013;27:6637-45.

[39] Dunleavy JK. Sulfur as a catalyst poison. Platin Met Rev 2006;50:110.

[40] Korte NE, Zutman JL, Schlosser RM, Liang L, Gu B, Fernando Q. Field application of palladized iron for the dechlorination of trichloroethene. Waste Manag 2000;20:68794.

[41] Tong YJ. Unconventional promoters of catalytic activity in electrocatalysis. Chem Soc Rev 2012;41:8195-209. doi:10.1039/C2CS35381D.

[42] McCue AJ, Anderson JA. Sulfur as a catalyst promoter or selectivity modifier in heterogeneous catalysis. Catal Sci Technol 2014;4:272-94. doi:10.1039/C3CY00754E.

[43] Angeles MJ, Leyva C, Ancheyta J, Ramírez S. A review of experimental procedures for heavy oil hydrocracking with dispersed catalyst. Catal Today 2014;220:274-94. 

doi:10.1016/j.cattod.2013.08.016.

513 [44] Forzatti P, Lietti L. Catalyst deactivation. Catal Today 1999;52:165-81. doi:http://dx.doi.org/10.1016/S0920-5861(99)00074-7.

[45] Byrne JM, Muhamadali H, Coker VS, Cooper J, Lloyd JR. Scale-up of the production of highly reactive biogenic magnetite nanoparticles using Geobacter sulfurreducens. J R Soc Interface 2015;12.

518 

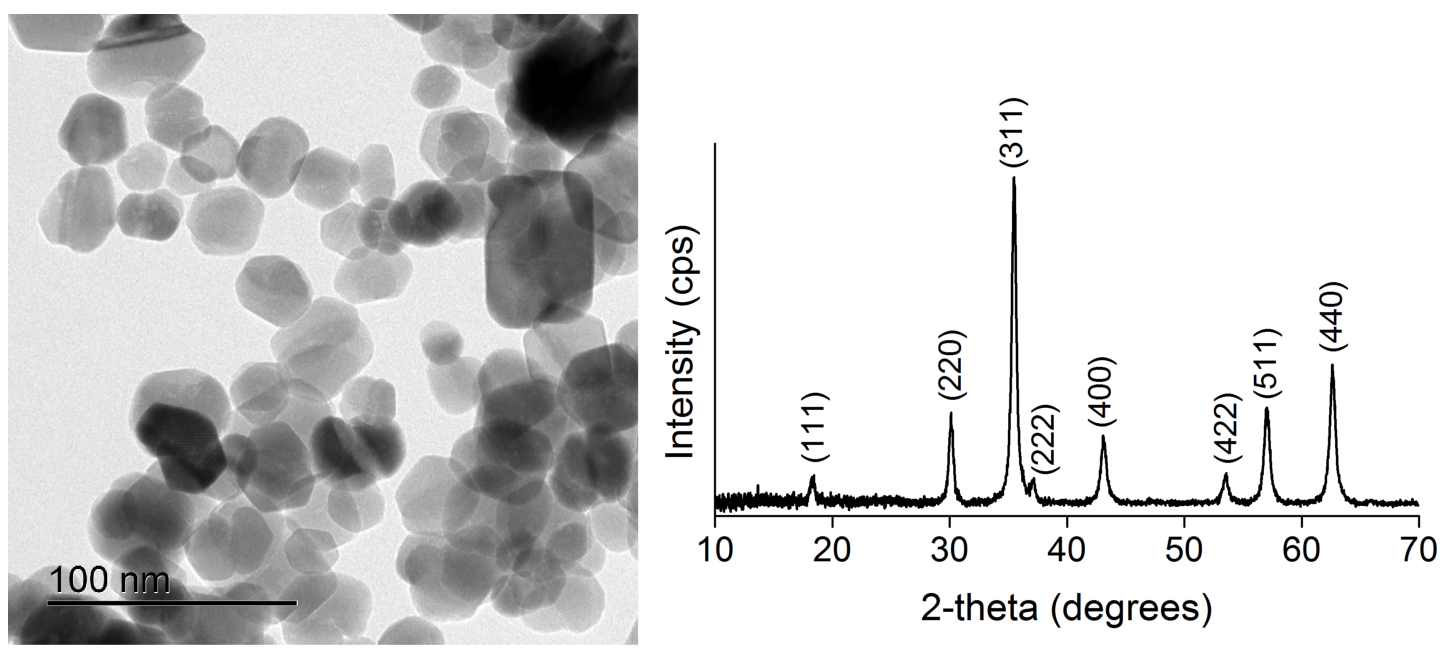

522 Fig. 1. Bright field TEM and powder XRD diffractogram of biogenic magnetite.

523

524

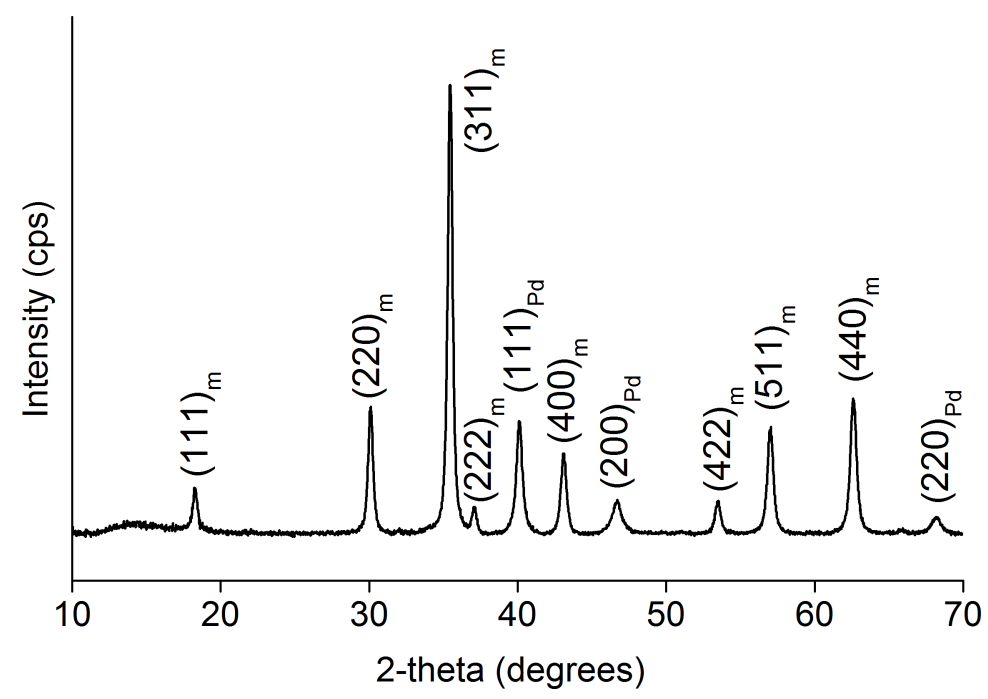

526 Fig. 2. XRD diffractogram of 9.5 wt. \% Pd-coated biogenic magnetite. 


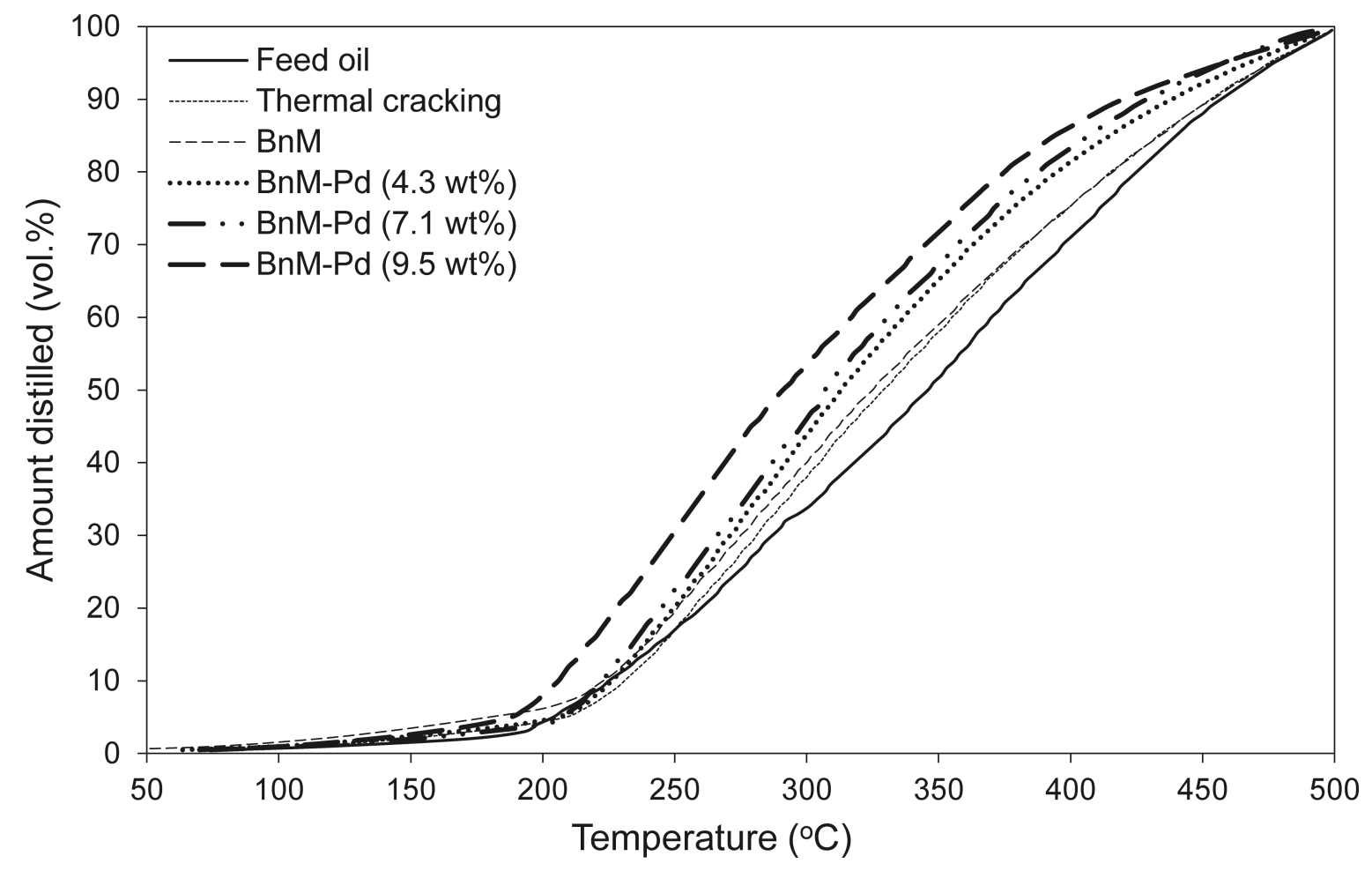

528 Fig. 3. True boiling point distribution curves of feed and upgraded oils after thermal cracking 529 and after reaction with Pd-coated biomagnetite (BnM). 